and implement retrospective conversion of the Alexander Turnbull Collection of pre-1801 imprints (approximately 9,500 titles) for the National Library of New Zealand, Wellington. His appointment ends in September 1990.

Dorothy C. Woodson, social sciences subject specialist at the State University of New York at Buffalo, will work with the special collections department at the University of Swaziland Library to identify and collect materials on Swaziland held in U.S. libraries. She will also help develop the Swaziana collection by advising on acquisition procedures. The appointment runs from October 1989 to August 1990.
Faye Powell, social science librarian at Portland State University, will advise on collection analysis and development at the American Studies Research Center in Hyderabad, India. Her appointment runs until January 1990.

Katherine Van de Vate, Arabic cataloger at Princeton University Library, will train 12 library employees in cataloging at the Asad National Library in Damascus, Syria, from April to September 1990 .

Library/Book Fellow positions available for 1990-1991 will be announced in late December 1989.

\title{
The 2nd Pacific Conference on New Information Technology
}

\section{By Augurio Collantes}

\author{
Catalog Librarian \\ Hostos Community College Library/CUNY
}

The 2nd Pacific Conference on New Information Technology, a non-profit forum for library and information professionals, educational media specialists, and technologists, was held on May 29-31, 1989, at the Glass Hotel in Singapore. It was designed to give librarians and information specialists from Asia and the Pacific region an opportunity to see for themselves some of the many information systems and products available in other parts of the world, to make them aware of the trends in information technology and their application to libraries, to enable them to talk about their accomplishments in the field, and to discuss their needs, interests, problems, and requirements with other knowledgeable colleagues.

More than 200 participants from the Asia/Pacific region and the United States were present. Due to logistical problems the location had to be changed from Bangkok to Singapore. The Library Association of Singapore and the Singapore Convention Bureau were kind and generous to co-sponsor the forum.

Ching-Chih Chen, chief organizer, opened the conference by looking back at the success of the First Pacific Conference held in Bangkok in 1987. The three official program days featured about 24 meetings where at least 74 papers were presented. Most of these were lectures or forums, contributed papers on topics ranging from $C D-R O M$, information retrieval, microcomputer applications, networks, databases to hypermedia, hypertext, and product reviews. Specific topics included Project ZEN (Zoom Encyclopedic Navigator) and ZGJKJ (Chinese Computer Science and Technology Documentation Database System) were discussed.

Exhibitors conducted informal talks to participants and they showed systems in operation. Companies based in Singapore had optical products, hypermedia applications, equipment, and software on display.

Especially for developing countries, funding to attend such regional conferences as this is a luxury unless you happen to live here. As an incentive the organizers offered free registration to paper presenters from the region and partial fellowships to some participants.

It is gratifying to learn of the efforts that librarians and information professionals in developing countries (particularly in Asia and the Pacific) have made in applying information technology in their respective organizations. Professional librarians in this area have the skills and knowledge; given the proper resources they could produce as much and bring out results that are at least comparable to those from the more developed countries.

A 480-page volume containing the conference papers was made available on opening day. Edited by Ching-chih Chen and David I. Raitt, the volume may be ordered for $\$ 57.50$ from MicroUse Information, 1400 Commonwealth Ave., West Newton, MA 02165. ISBN 0-931555-06-X. 


\section{ACQUISITION PERSPECTIVES}

1. ANY BOOK IN PRINT

means delivery to your library of all available books from any publisher or distributor in the U.S. or Canada. There is no list of publishers you must check ... WE DELIVER THEM ALL ... including trade, scientific/technical, text, university presses, paperbacks, associations, small presses, Canadian, and software.

Send us your direct orders and experience the "added value" received when using Book House.

\section{COMPHAH DATDAR}

\section{OPHN ORDAR RAPORHS}

4 ACCURFTH BOOR DHWWHE?

\section{CALL TOLL-FREE TODAY 1-800-248-1146}

In Canada \& Michigan CALL COLLECT (517) 849-2117

OCLC Vendor No. 17397 the

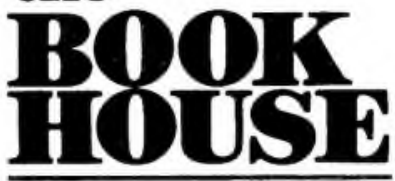

JOBBERS SERVING LIBRARIES WITH ANY BOOK IN PRINT SINCE 1962 208 WEST CHICAGO STREET JONESVILLE, MICHIGAN 49250 